\title{
Bahtsul Masail Sebagai Wadah Intelektual NU
}

\author{
Oleh Fathurozi \\ Staf Balai Penelitian dan Pengembangan Agama Semarang
}

Nahdhatul Ulama (NU) adalah organisasi keagamaan Islam (jam'iyyah diniyyah islamiyyah) terbesar di Nusantara. Organisasi yang berdiri pada tanggal 31 Januari 1926 di Jawa Timur. Pengikut jam'iyyah ini, memiliki tipologi unik, berbeda dengan pengikut organisasi keagamaan yang lain. Bagi pengikut Organisasi ini, biasanya di sebut "warga NU", dan memiliki ikatan emosional yang kuat dengan para Kyai pondok pesantren.

Tujuan didirikan NU adalah memegang teguh salah satu empat mazhab dan mengerjakan apa yang menjadi kemaslahatan bangsa. Namun sejalan dengan dinamika warganya tahun 50-an, NU terlibat politik Praktis (hlm, 1). Meskipun terjun ke politik, hingga sekarang masih mempertahankan keagamaan tradisional $(\mathrm{hlm}, 3)$.

Fajrul Falaah, Salah seorang tokoh muda NU, mencoba merangkum tiga alasan pokok berdirinya NU yakni, pertama, Aksi kultural untuk bangsa, yakni menggunakan strategi akulturasi dengan budaya setempat, dalam memperkenalkan Islam pada masyarakat. Kedua, Aktivitas yang mencerminkan dinamika berpikir kaum muda. Ketiga, usaha membela keprihatinan keagamaan internasional, yakni munculnya gerakan Wahabiyah yang berusaha menghilangkan segala khurafat yang ada di kota suci.

Namun, pendapat Fallaah disangga oleh Deliar Noer, salah seorang peneliti senior Indonesia menyatakan bahwa berdirinya NU merupakan respon atas faham reformisme pada awal abad ke-20 yang dikembangkan oleh Faqih Hasyim, salah seorang murid $\mathrm{H}$. Rasul, pembaharu terkemuka di tanah Minangkabau. Di Sumatra, respon atas kaum pembaharu berupa "Kaum Tua" yang mempertahankan tradisi-tradisi lama, sedangkan di Jawa dan sekitarnya muncul kelompok ulama Nahdatul Ulama. Namun alasan ini dibantah oleh Martin van Bruinessen, karena menurutnya, Noer kurang memberikan alasan yang representatif.

Merujuk pada catatan di negeri Belanda, menyebutkan bahwa organisasi NU (ulama tradisionalis) yang merupakan respon atas gerakan reformis, diprakarsai oleh Van Der Plas. Bagi Martin benar atau salah yang diungkapkan oleh Noer, yang terpenting memperhatikan bukti-bukti sejarah yang kuat, aspek reasonable juga perlu diperhatikan.

Dari persoalan berdirinya NU, jika NU merupakan gerakan responsif atas kaum pembaharu yang dikembangkan oleh Faqih Hasyim di Jawa Timur, kenapa NU tidak berdiri pada tahun belasan, disaat gencarnya gerakan pembaharu, (hlm, 2).

Lain lagi dengan pendapat pengamat NU dari Australia, Greg Barton dan Greg Fealy, menurut mereka sejarah perjalanan NU dibagi dalam 3 (tiga) periode yakni, periode awal sebagai organisasi keagamaan, sebagaimana organisasi keagamaan lainnya seperti Muhammadiyah, Persis dan Perti yang memiliki misi mengembangkan kegiatan-kegiatan keagamaan, pendidikan, ekonomi dan sosial.

Periode pertengahan atau sekitar tahun 1930, NU berubah fungsi menjadi partai politik dan bersama ormas lain mengadakan demo atas represi pemerintah kolonial Belanda, pasca 
kermerdekaan NU beserta Masyumi menjadi partai politik sebagai wahana umat islam. Tahun 1971, NU keluar dari Masyumi dan membentuk partai persatuan pembangunan (PPP). Dari kehampaan dalam dunia politik, NU kembali ke khittah 1926.

Periode ketiga, Periode ini sebagai tonggak sejarah baru NU dalam berkhidmat kepada bangsa dan negara. Kembalinya NU pada tujuan awal berdirinya yaitu sebagai aktivitas sosial keagamaan, atau lebih dikenal dengan kembali ke khittah 1926. Peristiwa ini dihasilkan pada Muktamar 1984 di Situbondo. Ide kembali ke khittah ini, dicetuskan oleh tokoh muda NU yakni, Abdurahman Wahid dan Ahmad Sidiq (hlm, 4).

Sejak kembali khittah, banyak bermunculan gagasan-gagasan segar dalam pembaruan hukum Islam (baca: fiqih) di kalangan NU. Menurut Clifford Geertz, Fikih bukanlah lembaga permanen yang bersifat sakral, tetapi fikih merupakan suatu produk peradaban (civilization product). Dengan begitu pemikiran fikih tidak lagi terkukung dengan rujukan teks (qauli) tetapi diimbangi dengan pembongkaran (dekonstruksi).

\section{Bahtsul Masail}

NU sebagai organisasi keagamaan mempunyai rasa tanggungjawab moral terhadap persoalan yang terjadi di masyarakat. Atas dasar ini lah, kemudian NU membentuk lembaga yang membahas segala persoalaan mulai dari politik, ekonomi sosial, budaya. Forum itu disebut Lajnah Bahtsul Masail (LBM). LBM merupakan lembaga atau forum yang memberikan fatwa hukum keagamaan kepada umat islam. Seperti yang tertuang dalam Anggaran Dasar dan Anggaran Rumah Tangga NU, dalam butir F pasal 16 menyatakan bahwa, tugas bahtsul masail adalah menghimpun, membahas dan memecahkan masalahmasalah yang mauquf dan waqi'iyah yang harus segera mendapatkan kepastian hukum (hlm, 39).

Bahtsul masail di kalangan NU diyakini merupakan tradisi intelektual yang berkembang sejak lama, bahkan ditengarai forum ini lahir sebelum NU dibentuk. Sebetulnya LBM telah berkembang di tengah masyarakat muslim tradisional pesantren jauh sebelum tahun 1926 dimana NU didirikan. Secara individual mereka bertindak sebagai penafsir hukum bagi muslimin di sekelilingnya ( $\mathrm{hlm}, 42$ ).

Berangkat dari sistem pengambilan keputusan hukum Bahtsul Masail yang dirumuskan pada Munas Bandar Lampung tahun 1992 ini, sebenarnya telah terjadi dinamika pemikiran hukum di lingkungan NU baik dari aspek substansi pembahasan maupun aspek metodologis. Bagi NU perumusan sistem ini sangat berarti bukan saja bagi para kyai yang terlibat langsung dalam arena bahtsul masail, tetapi bagi pengembangan wawasan berpikir masyarakat NU pada umumnya.

Seiring perjalannya waktu bahtsul masail mengalami masa suram dibawah kepimpinan $\mathrm{KH}$. Wahab Hasbullah, NU lebih fokus pada political oriented. Dari sini lah ulama dijajaran tanfidziyah maupun syuriah disibukan ke politik praktis. Tahun 1984 visi non-political disepakati, NU keluar dari politik (hlm, 95). Pada saat itu, NU konsentrasi pada problemproblem kemasyarakatan dan bahtsul masail mulai giat kembali.

Dalam pembahasan bahtsul masail tidak semua berkaitan dengan problem keagamaan. Hal ini dapat diamati dari hasil bahtsul masail tahun 1926 -1997 yakni, persoalan kesehatan 11,3 persen, politik 2,9 persen, ekonomi 11,6 persen, sosial masyarakat, 5,5 persen, advokasi 2,9 persen, perkebunan 3,13 persen dan keagamaan 62,16 persen (hlm, 45). 
Keputusan bahtsul masa'il di lingkungan NU, dibuat dalam rangka bermadzhab dengan salah satu madzhab empat yang disepakati dan mengutamakan bermadzhab secara qaul. Oleh karena itu dalam memberikan jawaban ittifaq hukum digunakan susunan metodologis sebagai berikut: 1). Dalam kasus yang ditemukan jawabannya dalam ibarat kitab dan hanya satu qaul (pendapat), maka qaul itu yang diambil. 2). Dalam kasus yang hukumnya terdapat dua pendapat maka dilakukan taqrir jama'i dalam memilih salah satunya. 3). Bila jawaban tidak diketemukan dalam ibarat kitab sama sekali, dipakai ilhaq al masail bin nadhariha secara jamai oleh para ahlinya. 4). Masalah yang dikemukakan jawabannya dalam ibarat kitab dan tidak bisa dilakukan ilhq, maka dilakukan istimbat jama'i dengan prosedur madzhab secara manhaji oleh para ahlinya $(\mathrm{hlm}, 6)$.

Dalam buku ini Imam Yahya berbicara tentang ide dasar konsep Metodologi bahtsul masail yang dirumuskan pada munas Lampung 1992. Tonggak Dinamika pemikiran hukum Islam dikalangan nadhiyin. Bahtsul masail dikalangan peneliti, dianggap hanya mempertahankan status quo tradisionalisme. Namun memiliki discourse intelektual yang berarti. Discourse intelektual meliputi, materi, objek dan metodologi.

$\begin{array}{ll}\text { Judul } & \text { : Dinamika ljtihad NU } \\ \text { Penulis } & \text { : Dr. Imam Yahya, M.Ag } \\ \text { Penerbit } & : \text { Walisongo Press } \\ \text { Tahun } & : \text { Cetakan Pertama, April } 2009 \\ \text { Tebal } & : 128 \text { halaman }\end{array}$

